\begin{tabular}{ll}
\hline 盗 料 & Informational Records \\
\hline
\end{tabular}

\title{
調剤による手指への微生物污染*1
}

林 弘㤑, 山田茂樹, 秋田昌宏, 小倉庸蔵, 椓田正彦, 須原清治 名占屋大学医学部附属病院薬剤部*2

\section{Contamination of Bacteria to Fingers by Dispensing*1}

\author{
HiRosuke Hayashi, SHIgeKi Yamada, MASAHIRo AKITA, \\ Youzou OGURA, MASAHIKo SinOda and KIYOHARU SUHARA \\ Pharmacy of Nagoya University Hospital*2
}

(Received October 2, 1981)

\begin{abstract}
Environmental sanitation in the dispensary is discussed in view of the probable microbial contamination of pharmacists to be caused in contact with prescriptions brought by patients. Following results were obtained :

1) In the pharmacists who prepared powder drugs, the number of microorganisms on their fingers recorded after 2-hour service preceded by handwashing was larger than that checked upon their arrival at the dispensary in the morning. In the positions of the dispensary where powder products were not handled, the bacterial contamination after 2-hour service was on almost the same degree as that immediately after pharmacists arrived at the dispensary. The total number after service was somewhat larger.

2) The number of microorganisms detected in the prescriptions was largest in those issued from the department of dermatology, followed by that from internal medicine and from ophthalmology, in that order. More microorganisms were detected in the fingers of pharmacists who touched highly contaminated prescriptions from the dermatologic department.
\end{abstract}

Keywords_-dispensing; prescription; fingers ; contamination; bacteria; fungi; gram-positive; gram-negative

病院薬局の環境衛生については種々の角度から検討さ れ, その改善に努力がなされている.病院薬局協議会に おいても「病院薬局の環境衛生のあり方」が議案として とりあげられ, 検討がなされている11. 著者らも粉塵, 騷音などについて検堮しすでに報告 ${ }^{2 \sim 4}$ しているが，今 回は外来調剤室において, 患者から提出された処方せ ん, 薬阂引換券など, あるいは調剤業務による薬局職員 への微生物污染について検討し, 若干の知見を得たので 報告する。

\section{実 験 の 部}

\section{実験方法}

薬局外来調剂室職員について, 朝出勤直後の手指の微

*1 本報を「病院薬局の環境衛生改善に関する䂙究」 第 4 報とする.日本薬学会第 100 年会（東京， 1980 年) で発表.

*2 名古屋市昭和区鶴 舞町 $65 ; 65$, Tsurumai-cho, Showa-ku, Nagoya, 466 Japan
生物を普通寒天培地で計測後, 流水, 石ヶン, グルコン 酸クロルヘキシジン（住友化学工業株式会社製ヒビテン グルコネート液) などにより手洗いを行い，無菌的なぺ 一パータオルでよく拭きとった後, 再び寒天培地により 手指の微生物を計測, 手指が微生物にほとんど污染され ていないことを確認後, 各調剤ポジション, すなわち鍩 剂調剂, 散剂調剂, 検薬, 書記・空口業務の 4 セクション に分けて 2 時間調剂を行った後, 再び手指への微生物感 染について測定した. 本院は外来診察室で患者が処方せ んを受け取り, 薬価会計空口にて支払い後, 薬剂引換券 と処方せんをもらい薬局に処方せんを提出, 調剤終了後 に薬阂引換券により薬剤を受領する. 外来調剤室は処方 せん枚数 $700 \sim 800$ 枚, 薬剂師 12 名, 薬剤補助員 5 名, 研修生若干名で, 調剤方式は流れ作業方式で各薬剤師は それぞれのポジションで自分の範用の薬品を調剤し，処 方せんと薬袋が移行していくシステムをとっている. 実験に用いた寒天培地は普通寒天培地, トリプトソイ 
寒天培地, サブロー寒天培地 (日本栄養株式会社製) を 規定にしたがい調製した. 真菌類測定用培地のサブロー 寒天培地には細菌の発育を抑制するためにクロラムフェ ニコール $400 \mu \mathrm{g} / \mathrm{ml}$, ストレプトマイシン $100 \mu \mathrm{g} / \mathrm{ml}$ を 加えた．培養時間は普通技よびトリプトソイ寒天培地は $37^{\circ} \mathrm{C}$ にて 48時間, サブロー寒天培地は 7 日閒培着し， 培地上のコロニー数を計測した.な掞, 患者から提出さ れた処方せんのらち各科毎に無作為に10枚ずつ取りだし たものと, 薬㶡引換券についてその微生物による污染度 を検討した。

さらに，培地上に計測したコロニーについて前報4) 同様に S. T. Cowan の方法らで細菌の同定を行った. 以上の実験は各ポジションで 2 名ずつ測定し, 各 3 回行 ってその平均值を求めた.

\section{結果と考察}

\section{1. 調剂前後における手指の污染}

出勤直後と手洗い後, 調剤 2 時間行った後の手指の微 生物污染について表 1〜3に示した.

表 1 の(1)は出勤直後, 普通寒天培地に各手指を押しつ け，48時間培養後の寒天培地上の各手指のコロニー総数 である. (2)は水道水の流水のみにて30秒手洗い後のコロ ニー数，(3)は手洗いしてから 2 時間調剂を行った後の堷 地上のコロニー数である.

表 2 の(2)は手洗いに石ケンを用いた場合，表 3 の(2)は 手洗いに $0.02 \%$ グルコン酸クロルヘキシジン液を用い 30秒間手洗いした時の表 1 と同様のコロニー数である.

朝, 種々の交通機関で出勤してきた者の手指の微生物 コロニー数は10個位から 100 個以上まで人によって大き な差があるが，調剤室 4 ポジションでの合計は約 200 個

表 1. 調剤前後における手指の污染 （流水による手洗，普通寒天培地）

\begin{tabular}{r|rrrrrc}
\hline & 散剂 & 錠剤 & 検薬 & 空口 & 合計 & $\overline{\mathbf{x}}$ \\
\cline { 1 - 7 }$(1)$ & 62 & 32 & 61 & 35 & 191 & 47.8 \\
$(2)$ & 7 & 7 & 13 & 5 & 32 & 8 \\
$(3)$ & 111 & 29 & 63 & 23 & 226 & 56.5 \\
\hline
\end{tabular}

表 2. 調剤前後における手指の污染 （石ケンによる手洗，普通寒天培地）

\begin{tabular}{r|rrrrrc}
\hline & 散剤 & 錠剤 & 検薬 & 㥶口 & 合計 & $\overline{\mathbf{x}}$ \\
\hline$(1)$ & 45 & 108 & 45 & 7 & 205 & 51.3 \\
$(2)$ & 5 & 6 & 8 & 1 & 20 & 5 \\
$(3)$ & 142 & 25 & 40 & 16 & 223 & 55.8
\end{tabular}

表 3. 調䬉前後における手指の污染 (0.02\%クロルヘキシジンによ 当手洗, 普通寒天培地)

\begin{tabular}{rrrrrrr} 
& 散昘 & 錠威 & 検楽 & 空口 & 合草 & \multicolumn{1}{c}{$\overline{\mathbf{x}}$} \\
\hline$(1)$ & 65 & 33 & 90 & 28 & 216 & 54 \\
$(2)$ & 3 & 3 & 4 & 1 & 11 & 2.8 \\
$(3)$ & 100 & 32 & 4 & 23 & 229 & 57.3
\end{tabular}

媊後のコロニーを培地上に認めた。これらの流水による 手指からの除去率は $83 \%$ ，普通の石ケンを用いての除去 率は $90 \%$ 前後, $0.02 \%$ グルコン酸クロルヘキシジン液 で30秒手洗いすると約 $95 \%$ の除去率となった。このよ うにして手指の微生物を除去した後，外来淍剤室におい て 2 時間業務後, 再び手指への微生物污染について測定 した結果，いずれの場合も出勤時よりわずかに多い微生 物を検出した。業務の種類によって，特に散剤調剂者に 多く検出され，その他のポジションでは人あるいは時に よって異なるがコロニー数は出勤時と大きな差はなかっ た．空い・分包業務での検计が比較似少なかったが，こ れは出勤直後の検出でも少なく，このポジションは薬剤 補助員の女子であり，女子は生理的にかあるいは常令清 潔につとめているからかは不明であるが，微生物による 污染は少なかった。手洗い後の業務による増加率として は $0.02 \%$ グルコン酸クロルヘキシジン液を用いた捗が 最も少なかった.グルコン酸クロルヘキシジン液はその 能書に一般消毒 (手指, 家具, 器具類) の使用濃度と乙 て $0.02 \%$ とあるが, 表 3 に示したように30秒の手洗い ではまだ 5 〜 $6 \%$ の微生物が手指に残る。これは日常生 活に拈いては差しつかえないかも知れないが, 病院の業 務に揖いては，特に手術のような無菌の状態を求める業 務でないといえども好ましいことではないので，手洗い を $0.05 \%$ グルコン酸クロルヘキシジン液を用いて行 い，その結果を䒾4に示した。

$0.05 \%$ グルコン酸クロルヘキシジン液で 30 秒手洗い を央施すると，その手指の微生物は $99 \%$ 以上除去する ことができるが，まだ時折りコロニ一を検出することが あるので，無菌製剤などの業務については注意が必要で

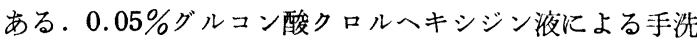
い後の 2 時間の業務において初めて朝の出勤時よりるこ ロニ一数が減少した。このことは $0.05 \%$ グルコン酸ク ロルヘキシジン液に30秒浸漬することにより手指にク口 ルヘキシジンの被膜を作り，これによって手指への微生 物污染が減少したものと考える。このクロルヘキシジン の被膜形成については手術時の長時間清潔維持について 岩佐ら ${ }^{6)}$ も認めており, クロルヘキシジンの手指への吸 
表 4. 調剤前後における手指の污染 (0.05\%クロルヘキシジンによ る手洗，普通寒天培地）

\begin{tabular}{r|crrrrr} 
& 散剤 & 錠郕 & 検薬 & 空口 & 合計 & \multicolumn{1}{c}{$\overline{\mathbf{x}}$} \\
\hline$(1)$ & 36 & 76 & 50 & 4 & 166 & 41.5 \\
$(2)$ & 0.5 & 1 & 0 & 0 & 1.5 & 0.4 \\
$(3)$ & 72 & 15 & 30 & 18 & 135 & 33.8
\end{tabular}

着は浸漬時間10分で飽和量に近づくといわれている.7

\section{2. 真菌视による污染}

表 $1 \sim 3$ と同様に培地として真菌類測定用のサブロー 寒天培地を用い測定したが，出勤時，業務終了後ともす べて培地上にコロニーは認められなかったので, 真菌類 による手指の污染はほとんどなかったと考える。

\section{3. 調刋栄场による各手指への污染}

表 1 亿おける出勤直後(1)之流水にて手洗い後, 調刜業 務を 2 時間行った薬剤師の各手指への微生物污染(3)のバ ラッキについて検討し表 5 に示した。表 5 に示したよう に(1)の出勤直後は親指, 人差し指, 中指にやや多くの微 生物を検出したが，(3)の調剤業務終了後の各手指の微生 物污染は親指, 人差し指, 中指へさらに顕著に多くの微 生物が付着し，承指，小指には非常に少なかった。これ は調剂業務には親指, 人差し指，中指の各手指を多く使 らためであろうと考える。

表 5. 調剤業落化よる各手指への污架 （流水による手洗，普通寨天培地）

散 刻錠 郕 検 薬合 計 $\overline{\mathrm{x}}$

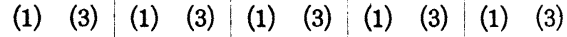

\begin{tabular}{|c|c|c|c|c|c|c|c|c|c|}
\hline 親 指 & 33 & 42 & 13 & 7 & 41 & 19 & & 68 & 29 \\
\hline 人差し指 & 11 & 28 & 9 & 11 & 7 & 14 & 27 & 53 & 9 \\
\hline 中 指 & 13 & 26 & 5 & 6 & 7 & 26 & 25 & 58 & 8 \\
\hline 指 & 4 & 12 & 3 & 3 & 2 & 3 & 9 & 18 & 3 \\
\hline 小 指 & 1 & 3 & 3 & 1 & 4 & 2 & 8 & 6 & 3 \\
\hline
\end{tabular}

\section{4. 処方せん，莱耕引澳券の微生物污染}

調剂室の微生物污染の污染源の一つとして, 患者が各 診察室より受け取り外来調剂室へ提出する処方せん，あ るい抙薬剤引換券などが考えられるので，各科の処方せ んのらち内科, 眼科, 皮店科の 3 科の処方せん各10枚化 ついてトリプトソイ寒天培地, サブロ一寒天培地により 表面の微生物污染について計測した。また，同様に患者 の提出した薬剤引換券についてもその表側, 裏側につい て計測し，表 6，7亿示した。なお，対照として診察室 より末使用の 3 科の処方せん，未使用の薬剤引換券につ
いても計測した。

本院の処方せんは B 5 判複写式で，これを患者が診察 室より受け取り，会計の時点で分け表側のみ薬局へ提出 するため，処方せんについては表側の及測定し表 6 に示 したが，その污染度は皮膚科の処方せんが最も多く，眼 科が少なかった。な拉，手指からはサブロ一培地による 真菌類は認められなかったが，一部の処方せん上より真 菌類, 特にカビによる污染を計測した。

患者が提出した薬剤引換券10枚について同様計測した ものが表 7 である. 薬剤引換券は表側の污染度が高く， 裏側に比べ約 4 倍あった。これは本院の引換券は裏側に カーボンが塗ってあり患者が手がよごれないように折っ て持っていることが多いためであろらと考兄る. サブロ 一培地佀よる真菌類は引換券からは検出されなかった。 な怙，処方せんと薬剤引換券との単位面積に打ける生菌 数は処方せんの最も少なかった眼科より, 薬剤引換券の

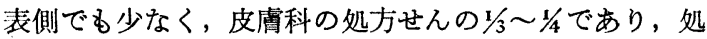
方せんの方が微生物污染が大であった。

表 6. 処方せんの微生物污染

\begin{tabular}{|c|c|c|c|c|c|c|}
\hline 科 & 名 & 地 & 平 均 & 大 & 最 少 & 未使用 \\
\hline 内 & 科 & $\begin{array}{l}\text { トリプトソイ } \\
\text { サブロ - }\end{array}$ & $\begin{array}{r}189 \\
2\end{array}$ & $\begin{array}{r}356 \\
2\end{array}$ & $\begin{array}{r}49 \\
0\end{array}$ & $\begin{array}{l}1 \\
0\end{array}$ \\
\hline 恨 & 科 & $\begin{array}{l}\text { トリプトソイ } \\
\text { サプロ - }\end{array}$ & $\begin{array}{r}124 \\
0\end{array}$ & $\begin{array}{r}198 \\
0\end{array}$ & \begin{tabular}{r|r}
43 & \\
0 &
\end{tabular} & $\begin{array}{l}0 \\
0\end{array}$ \\
\hline & & $\begin{array}{l}\text { トリプトソイ } \\
\text { サブロ - }\end{array}$ & $\begin{array}{r}334 \\
1\end{array}$ & $\begin{array}{r}454 \\
2\end{array}$ & $\begin{array}{r}236 \\
0\end{array}$ & $\begin{array}{l}0 \\
0\end{array}$ \\
\hline
\end{tabular}

表 7. 引換券の微生物污染

\begin{tabular}{|c|c|c|c|c|c|}
\hline & 地 & 平 均 & 最 大 & 最 少 & 未使用 \\
\hline \multirow[t]{2}{*}{ 表 } & トリプトソイ & 23 & 33 & 14 & 0.5 \\
\hline & サプロ- & 0 & 0 & 0 & 0 \\
\hline \multirow{2}{*}{ 輂 } & トリプトソイ & 6 & 9 & 3 & 0 \\
\hline & サブロ - & 0 & 0 & 0 & 0 \\
\hline
\end{tabular}

\section{5. 処方せんより手指への活染}

表 6 に示したように, 処方せんは比較的微生物污染度 が高く，これを扱ら調剤者への微生物感染が考兄られる ので $0.02 \%$ グルコン酸クロルヘキシジン液で 30 秒以上 手洗いした後, 患者の提出した内科, 眼科, 皮䖉科の処 方せん各 5 枚に各々手指を接触, 塗擦した後の手指への 微生物感染を検討した結果を表 8 に示した.

$\mathrm{A} \sim \mathrm{F}$ の各 6 名の被験者により，3 科からランダムに 


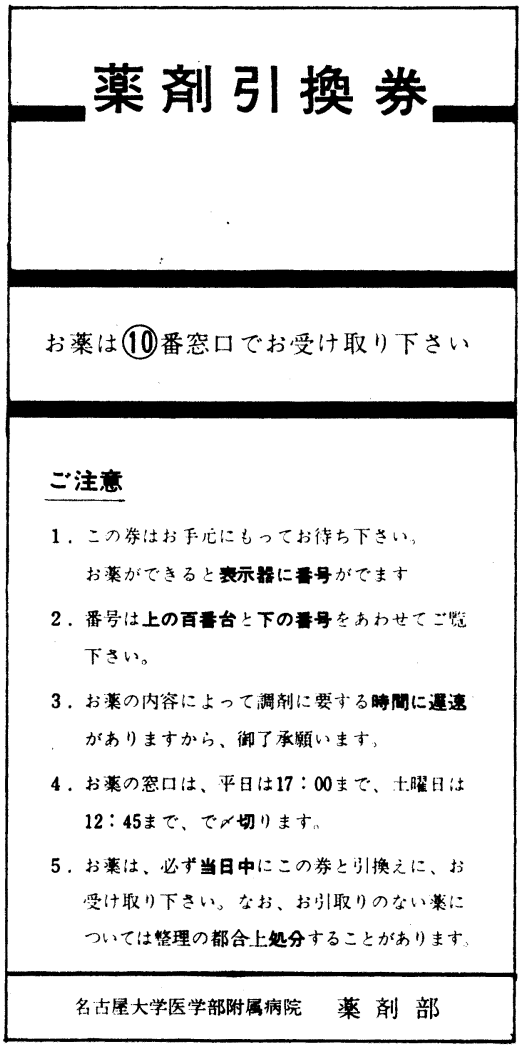

図 1. 薬剤引換券 (寒カーボン)

拔きとった処方せんに手指をこすりつけるようにすると 表 8 に示したように皮䖉科の処方せんに接触したものに 微生物污染が最も多く, 眼科が最も少なかった。これは 表 6 の処方せん污染度に比例し, 污染度の高い処方せん に接するほど手指への感染が大となるということができ る.

\section{6. 手指細菌の同定}

出勤直後と $0.05 \%$ クロルヘキシジン液で手洗い後, 2 時間業務を行った後の手指より培養した細菌のコロニ 一について前報4) 同様に細菌の同定を行い, その結果を 表 9 に示した。

手指の細菌を培地上に採取すると非常に狭い範囲に多 数のコロニーとなり, 特に業務後の散剂調剂者のように 100 個以上のコロニーを検出した場合は各コロニー間が 接触してしまい, 細菌の同定が不可能となるため, この ポジションの同定可能は全体の1/2〜1/3となった. 散剂調 剤者を除く各ポジション全コロニーと散剤調剤者の測定 可能のコロニーについて細菌の同定を行った. その結果 業務前後ともグラム陽性菌がグラム陰性菌よりはるかに
多かった．これは笠置, ${ }^{8}$ 古橋9) らす指摘しているが, 著者らにおいてもほぼ同じような結果が得られた。グラ ム陰性菌については桿菌が多く, 出勤直後にはグラム陰 性球菌を検出しなかったが業務後には Neisseria をわず かに検出した、調郕業務前後におけるグラム染色による 分類では顕著な差はなかったが，グラム陽性球菌は表 9 に示したとおり業務終了後に Staphylococcus コアグラー ゼ（一）が少なく，その他の細菌がやや多くなった。ま た前報）において Staphylococcus aureus のコアグラー ゼ（十）を検出したが, 今回の手指からは検出せず, 病 原性のない常在菌がほとんどであったと考える.

調剂業務に拈ける手指の污染は散剂調剤が最も多く, 出勤時より多いュロニーを検出したが，他の業務におい てはあまり差はなかった。しかし, 患者から薬局へ提出 される処方せん, 薬昘引換券などは微生物による污染度 が高いほど手指への感染が大となり，また，今回は検出 されなかったが病原性微生物による污染の可能性すある ため, これらによる注意が必要である. 手洗いについて は当然クロルヘキシジン液を用いるのが有効であるが， 特に $0.05 \%$ 以上の濃度を用いると手指への被膜により 業務による污染をある程度防止することができる。ま た，流水のみでも手指微生物の除去が比較的よくできる ので, 調剤者はよく手洗いを励行して, 薬剂への再污染 防止につとめなければならないと考える。

表 8. 処方せんより手指への污染 (トリプトソイ寒天培地)

\begin{tabular}{|c|c|c|c|c|c|c|c|}
\hline 科 名 & A & B & $\mathrm{C}$ & $\mathrm{D}$ & $\mathrm{E}$ & $\mathrm{F}$ & $\overline{\mathbf{x}}$ \\
\hline 内 科 & 6 & 3 & 11 & 7 & 6 & 2 & 5.8 \\
\hline 眼 科 & 3 & 1 & 8 & 5 & 4 & 1 & 3.7 \\
\hline 皮府科 & 14 & 6 & 44 & 16 & 16 & 5 & 16.8 \\
\hline
\end{tabular}

表 9. 手指細菌の同定

\begin{tabular}{|c|c|c|c|c|}
\hline & & & $\begin{array}{l}\text { 業務前 } \\
(\%)\end{array}$ & $\begin{array}{l}\text { 業務後 } \\
(\%)\end{array}$ \\
\hline \multirow{5}{*}{ グラム陽性菌 } & \multirow{3}{*}{ 球菌 } & $\begin{array}{l}\text { Staphylococcus } \\
\text { coagulase }(-)\end{array}$ & 75.0 & 53.9 \\
\hline & & Micrococcus & 8.8 & 3.8 \\
\hline & & その他の球菌 & 5.0 & 30.8 \\
\hline & \multirow{2}{*}{ 桿菌 } & Bacillus & 1.3 & 3.9 \\
\hline & & その他の桿菌 & 5.0 & 1.9 \\
\hline \multirow{2}{*}{ グラム陰性菌 } & 球菌 & Neisseria & 0 & 1.9 \\
\hline & 桿菌 & その他の桿菌 & 5.0 & 3.9 \\
\hline
\end{tabular}


結

果

病院薬局の外来调殽に拈いて，患者の提出した処方过 んなどにより，調剂時に薬局職員への微生物污染につい て検討し，次の結果を得た。

1. 薬局職員の出勤時の手指の微生物生菌数之手洗い 後 2 時間業務を行った後の微生物生菌数は, 散剂調剂者 には多くなるが，他のポジションでは出勤時とほとんぞ 同じであり，合計では調剤業務後はややコロニー数が多 くなった。しかし，手洗いに $0.05 \%$ グルコン酸クロル ヘキシジン液を用いると調剂業務終了後の方が逆に少な くなった。また微牛物のらち手指からは真菌類の検出は されなかった。

2. 患者の提出した処万せ九のらち, 内科, 眼科, 皮

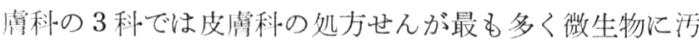
染されて捻り，眼科が最も少なからた。また，処方せん からは真菌類も一部検出された。このような処方せんに 接触した時，污染度の高い皮膚科の処方せ几に挍触した 人の手指に，より多くの微牛物が検出された。
3. 手指から検出した細菌はグラム陽性菌がグラム陰 性藏より多く，中でもグラム陽性球菌が多かった。グラ ム隍性菌では桿菌の方がわずかに多く検出された。

交献

1) 朝長文弥, 堀岡正義, 平岡栄一, 梅沢修, 黒田 健, 武信員夫, 細田順一, 小林輝明 : 病院薬学, 7, 59 (1981).

2) 林弘祐, 秋田昌宏, 近藤源作, 須原清治: 病院 薬学, 6, 220 (1980)

3) 林弘祐, 秋田昌宏, 須原清治, 松本忠雄, 中川 武男：病院薬学，7,245(1981).

4) 林弘祐, 山田茂樹, 秋田昌宏, 小倉庸蔵, 須原 清治 : 病院薬学, 7, 370 (1981).

5) S. T. Cowan : Manual for the Identification of Medical Bacteria 2nd ed.

6) 岩佐 博, 古橋正吉 : 外科彰療, 14,116 (1972).

7) 細淵和成, 佐藤健二, 小林寛伊, 高橋泰子, 都築 正和：第 2 回手術部研究会講演要旨, 1980 年 10 月, 東京。

8）笠置 達：日外会訫，69，1（1968).

9) 古橋正吉：外科治療, 26, 407 (1972)

\section{外科領域のプロスタグランジン}

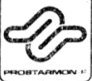

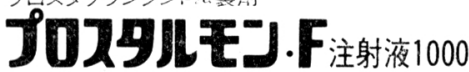

適応症

I 静衇内注射投与

1. 妊娠末期における陣痛誘発・陣痛促進・ 分婏促進

2、下記における腸管蠕動立進

・胃腸管の手術における術後晹管麻瘁 $\sigma$ 回復遷延の場合

・麻瘏性イレウスにおいて他の保存的治 療で効果が認められない場合 II 卵膜外投与

治療的流産

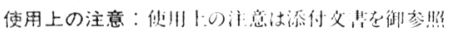
रो:yl,

○適応症により[用法・用量〕、及ひ〔使用上の注意〕 か異なりますのでこ注意ください 